\title{
Measuring Performance of Reverse Supply Chains in a Carpet Manufacturer
}

\author{
Maulida Butar Butar \\ University of Portsmouth, Portsmouth, United Kingdom \\ Email: mde80356@myport.ac.uk \\ David Sanders, Regina Frei \\ University of Portsmouth, Portsmouth, United Kingdom \\ Email: $\{$ david.sanders, giles.tewkesbury, regina.frei\}@ port.ac.uk
}

\begin{abstract}
Increasing attention has been given to the reverse supply chain because of the increasing value of products and technology at the end of direct supply chains as well as the impact of new green legislation. Design strategies for reverse supply chains have remained relatively unexplored and underdeveloped. Meanwhile measuring supply chain performance has also become important as understanding, collaboration and integration has increased between supply chain members. It has also helped companies to target profitable market segments or identify areas for service improvement. This paper will focus on measuring performance of reverse supply chains in carpet manufacturers. A simple general framework of the company is presented as well as mathematical models. This simple general model can be to be applied by small medium enterprises to optimise their reverse supply chain systems.
\end{abstract}

Index Terms - Reverse supply chain, carpet recycling, performance measurement

\section{INTRODUCTION}

Reverse supply chains deal with the backward flow of products recovered from users. The role of a Reverse Supply Chain (RSC) or reverse logistics (used interchangeably) is increasing in many industries such as the automobile industry, consumer electronics, book publishers, catalogue retailers and so on [1]. Reverse Supply Chains have become a relevant topic not only for academics and the business world. Companies are giving more and more importance to this field, mainly for two reasons: first, the environmental issues and the impact of these issues on the public opinion; second the benefits that a company can obtain by the improvement of their return's processes.

Increasing attention has also been given to the RSC due to the increasing value of products and technology. Products, parts, subassemblies, and materials represent rapidly growing values and economic opportunities at the end of the direct supply chain [2].

The rate of return varies by industry. Some industries have high percentages of returns such as apparel, internet retailers, or computer manufacturers while others have lower percentages [3].
Unlike forward supply chains, strategies for reverse supply chains are relatively unexplored and underdeveloped [4]. However, product returns and their reverse supply chains represent an opportunity to create a value stream, not an automatic loss. Therefore, reverse supply chains should be managed business processes that can create profit for a company. Although reverse supply chains and performance measurement have been discussed widely in the literature, performance measurement in reverse supply chains needs further investigation [5].

This paper will focus on performance measurement in a carpet reverse supply chain, particularly on carpet recycling and refurbishing facilities. This paper introduces:

1. A prototype model for returned product flow at a carpet manufacture company.

2. Testing of the prototype with mathematical models using cost as a performance metric.

3. Areas that could be improved for better reverse supply chain performance.

\section{BACKGROUND}

\section{A. Reverse Supply Chains}

A reverse supply chain (RSC) is a series of activities required to retrieve a used or unused product and either dispose of it, reuse it, or resell it [6].

Companies have an option to close the RSC or leave it open. Leaving it open means the products in a reverse supply chain will go to different destinations from the original supply chain. Supply chains could also be made by creating a loop. This closed loop supply chain consists of a reverse supply chain and closed loop to connect it to the original forward supply chain [7]. Guide and Wassenhove [8] stated that companies that had been most successful with their RSC were those that closely coordinated them with their forward supply chain, creating a closed-loop system.

To make rational decisions about the structure of a reverse supply chain, Guide and van Wassenhove [9] declared it best to divide a chain into five key components and then to analyse options, costs and benefits for each of them. To understand the whole 
concept of RSC, some characteristics had to be investigated. The characteristics are illustrated in Figure 1.

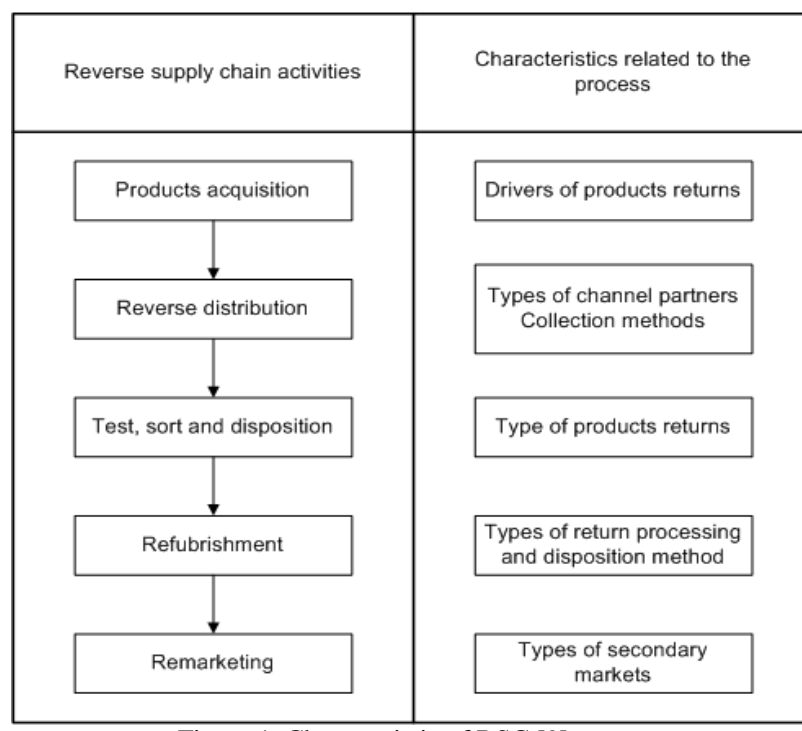

Figure 1. Characteristic of RSC [9]

Users may return products for different reasons at different stages in the product lifecycle [10]. Numerous classifications of product returns have been given by several authors in the past according to different categories and some are shown in Table 1.

TABLE I

\section{CLASSIFICATION OF PRODUCT RETURNS}

\begin{tabular}{|l|l|}
\hline Authors & $\begin{array}{c}\text { Categories of Product } \\
\text { Returns }\end{array}$ \\
\hline Rogers and Tibben-Lembke [11] & Reverse flow of products \\
& Reverse flow of packaging \\
\hline De Brito and Dekker [12] & Manufacturing phase \\
& Distribution phase \\
& Customer use returns \\
\hline
\end{tabular}

Paterson [13] said that better management of reverse supply chains translated into better customer service and consequently, higher customer satisfaction. Industries and the enterprises within them are also realising that management of the reverse supply chain is a revenue opportunity.

One factor in achieving an effective reverse supply chain is an efficient establishment of schedules, transportation and networks [14]. Fleischmann et al [15] described a network model for a recovery network. There were three facilities involved:

- disassembly centres which house inspection and separation activities,

- factories for reprocessing and/or new production,

- and distribution warehouses to keep an inventory of unprocessed and processed returns.

In reverse supply chains, there are additional processes compared with forward supply chains. The processes are dependent on the condition (quality) of returns and appropriate channels need to be chosen based on recovery options [16]. For example, in the aircraft industry, very high quality is required to safely assurance.
Thierry et al [17] presented a category of product recovery options where each of them implied collection of used products and components, reprocessing and redistribution. The only thing that was different involved reprocessing activities. There were five main activities: repairing; refurbishing; remanufacturing; cannibalisation (in the context of component reuse) and recycling.

The definition used is that a Recovery Plant facility is where parts are refurbished, while a Manufacturing Plant is where parts are produced.

TABLE II. TYPICAL INDIVIDUAL PERFORMANCE MEASUREMENT [18]

\begin{tabular}{|c|c|c|}
\hline $\begin{array}{l}\text { Performan } \\
\text { ce objective }\end{array}$ & $\begin{array}{l}\quad \text { Some typical } \\
\text { performance } \\
\text { measures }\end{array}$ & $\begin{array}{l}\text { Performance criteria that } \\
\text { link firm strategy to } \\
\text { operations decisions }\end{array}$ \\
\hline Quality & $\begin{array}{l}\text { Number of defects } \\
\text { per unit. } \\
\text { Level of customer } \\
\text { complaints. } \\
\text { Scrap level. } \\
\text { Warranty claims. } \\
\text { Mean time } \\
\text { between failures. }\end{array}$ & $\begin{array}{l}\% \text { defect reduction. } \\
\% \text { scrap value reduction. } \\
\% \text { unscheduled downtime } \\
\text { reduction. } \\
\% \text { supplier reduction. } \\
\% \text { of inspection } \\
\text { operations eliminated. }\end{array}$ \\
\hline $\begin{array}{l}\text { Speed or } \\
\text { innovation }\end{array}$ & $\begin{array}{l}\text { Customer query } \\
\text { time. } \\
\text { Order lead time. } \\
\text { Frequency of } \\
\text { delivery. } \\
\text { Actual versus } \\
\text { theoretical throughput } \\
\text { time. } \\
\text { Cycle time. }\end{array}$ & $\begin{array}{l}\text { \% increase in annual } \\
\text { investment in new product } \\
\text { and process research and } \\
\text { design. } \\
\% \text { reduction in material } \\
\text { travel time between work } \\
\text { centres. } \\
\% \text { increase in annual } \\
\text { number of new products } \\
\text { introduction. } \\
\% \text { increase in common } \\
\text { parts per products. }\end{array}$ \\
\hline $\begin{array}{l}\text { Dependabi } \\
\text { lity }\end{array}$ & $\begin{array}{l}\text { Percentage of } \\
\text { orders delivered. } \\
\text { Average lateness } \\
\text { of orders. } \\
\text { Proportion of } \\
\text { products in stock. } \\
\text { Schedule } \\
\text { adherence. }\end{array}$ & $\begin{array}{l}\text { \% reduction in purchased } \\
\text { lead time. } \\
\% \text { reduction in lead time } \\
\text { per product line. } \\
\% \text { increase in portion of } \\
\text { delivery promises met. }\end{array}$ \\
\hline Flexibility & $\begin{array}{l}\text { Variance against } \\
\text { budget. }\end{array}$ & $\begin{array}{l}\text { \% inventory turnover } \\
\text { increase. } \\
\% \text { reduction of employee } \\
\text { turnover. } \\
\% \text { improvement in } \\
\text { labour/desired labour. } \\
\% \text { reduction in total } \\
\text { number of data transactions } \\
\text { per product. } \\
\% \text { average set-up time } \\
\text { improvement per product } \\
\text { line. }\end{array}$ \\
\hline
\end{tabular}

\section{B. Performance Measurement}

Performance measurement is often discussed but rarely defined. Neely et al [19] said that measurement is the process of quantification and action correlates with performance. They also proposed that performance should be defined as the efficiency and effectiveness of action.

There are many reasons why companies measure their performance. Cuthbertson and Piotrowicz [20] mention measuring supply chain performance to increase understanding, collaboration and integration between 
supply chain members. It also helps companies to target profitable market segments or identify a suitable service definition. Furthermore, performance measurement is an activity to reach predefined goals derived from company's strategy objectives [21].

There are a large number of performance measures discussed in the literature. In the earlier literature, performance measures were usually divided into costrelated and non-cost-related performance measures. Stock [22] classified a group of individual performance measures based on the terms of the five manufacturing performance objectives: quality; speed; dependability; flexibility and cost. In Table 2, examples of different performance measures are listed under these five categories.

\section{Reverse Supply Chain at a Carpet Company}

Over 4.7 billion pounds of post-customer waste carpet were discarded. And $95 \%$ of it is going to landfill as disposal each year just in US [23]. Increasing concerns about disposal capacity combined with carpet bulk that make it difficult and expensive to handle, have contributed to a search for alternative means for carpet disposal. Recovery processes in carpet industry are needed. Not only could it save numerous production costs and increase profit but it could also encourage environmental concerns. Key factors in recycling are collection, sorting and recovery, recycling and disposal, as shown in Figure 2. This figure is a simplified flow diagram for carpet recycling.

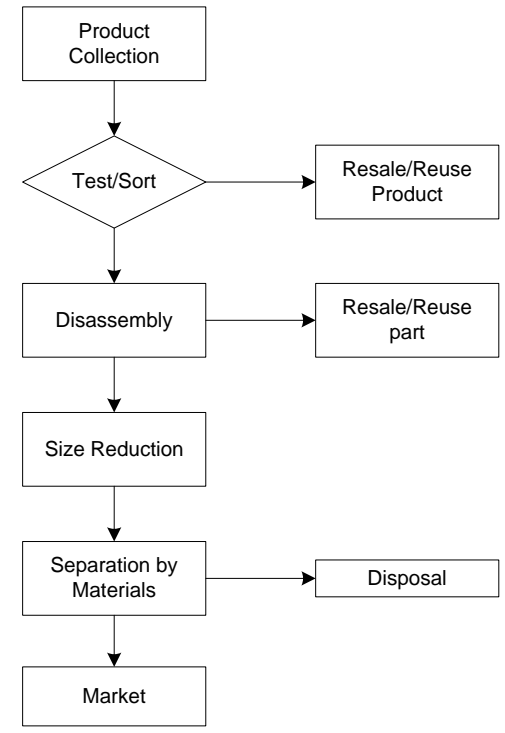

Figure 2. Simplified flow diagram for carpet recycling

The returned products are collected from many widespread sources and consolidated for further inspection, handling and processing. Therefore, reverse logistics is more complex than forward logistics as there are many actors involved in the processes. Because the reverse shipments tend to be smaller, less frequent and mixed, the costs of transportation, handling and inventory holding for reverse logistics are always higher than forward logistics for new products [11].
In this paper, remanufacturing of a product is used as a way to reduce production cost compared to producing new products (in terms of less new material and less manufacture process required) while reducing environment a cost at the same time.

Based on existing literature, a first prototype of a reverse supply chain network for the carpet industries is presented in Figure 3. In this paper, a user described the input for a returned product, re-transformers were where all recovery activities took place (called a central recovery centre) and brokers were a second market.

Figure 3. First prototype carpet reverse supply chain network

\section{COMPANY BACKGROUND}

The company considered in this paper is based on a case study from 2009 [24] . The company focused on carpet manufacturing and recycling as the main activities. This paper concentrates on the refurbishment of returned carpets as one of the company activities.

Returned carpet from customers (either individual or organisation) were sent to a recovery centre and received in a recovery centre warehouse. In the recovery centre, returned carpets were processed based on the conditions of the products. Mechanical and chemical process will converted the carpet into raw materials. The conversion processes is referred to as a disassembly process and refurbishment process, where nylon polymer in used carpet was converted to monomer units which could be used as raw material in carpet manufacture. This process was called depolymerisation. There are three main types of materials related to carpet manufacturing: yarn, which is nylon; chemical products such as polypropylene and polyester; and finally, the package [24].

Carpet reverse supply chains have an obstacle which is challenging. There is uncertainty about both demand and offer. Both the arrival times and the quantities of returned carpet are usually unknown ahead of time and generally difficult to predict. 


\section{MATHEMATICAL MODEL}

In this model, a warehouse in the recovery centre received all returned carpets from the customer. Products were disassembled and processed until they became raw materials ready to be shipped to manufacturing plants. This action took place at the Recovery Centre.

All of the returns due to end of life type products were shipped to the recovery centre. The recovery facility processed the returns and sent the reusable materials as raw material to manufactures, depending on the demand requested from them.

For return parts, assume that only nylon could be used to re-manufacture; all else was disposed. Manufactures purchased raw materials from suppliers then shipped finished products to the warehouse according to the demand requested, then the products will be shipped to retails/customers.

Returned products underwent few stages of disassembly. The first stage was usually carpet size reduction, followed by chemical separation of carpet components. Separated nylon was processed to be used as raw material [25]. Figure 4 shows the level of disassembly processes in a recovery centre. Useful

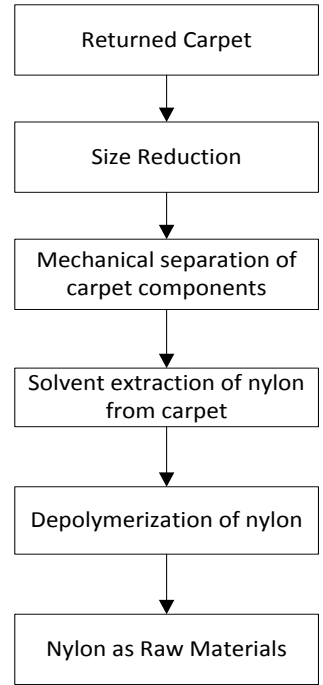

Figure 4. Level of disassembly process[25]

At the manufacturing plant, the additional material from returned products was used together with new materials to make new products that were stored and then shipped to distributors for sale. Figure 5 shows a general

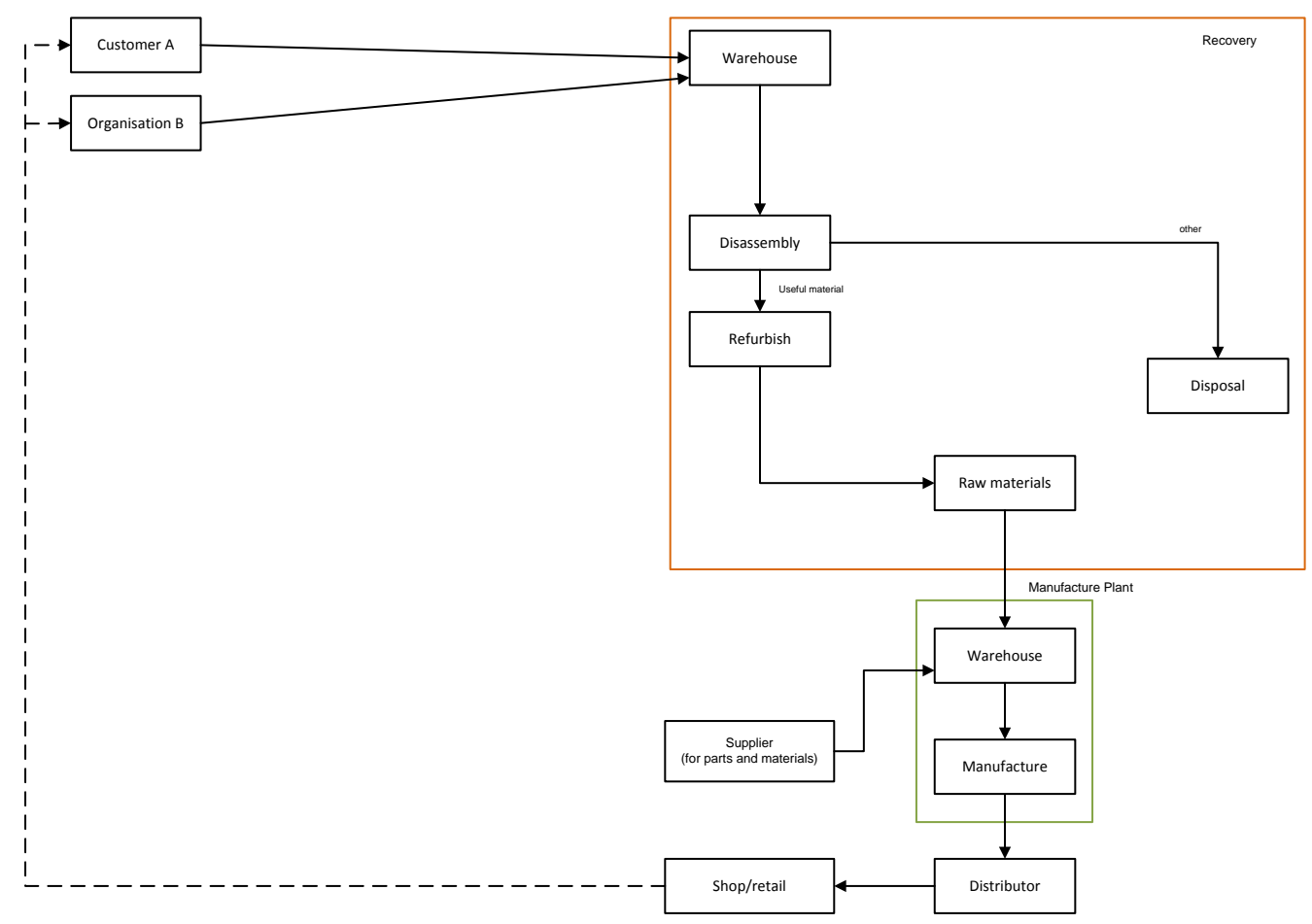

Figure 5. General Model of product flows

materials were refurbished for re-use at a manufacturing plant. Other parts were sent to landfill. All raw materials from the recovery centre were sent to a manufacturing plant to be used as raw material in the production process. model of product flow.

Company performance is considered with respect to

cost optimisation. The objective of the company is to minimise cost. A mathematical model was created based on the case study. The model can be used to consider minimising cost.

The mathematical model is the sum of all the costs associated with the process. 


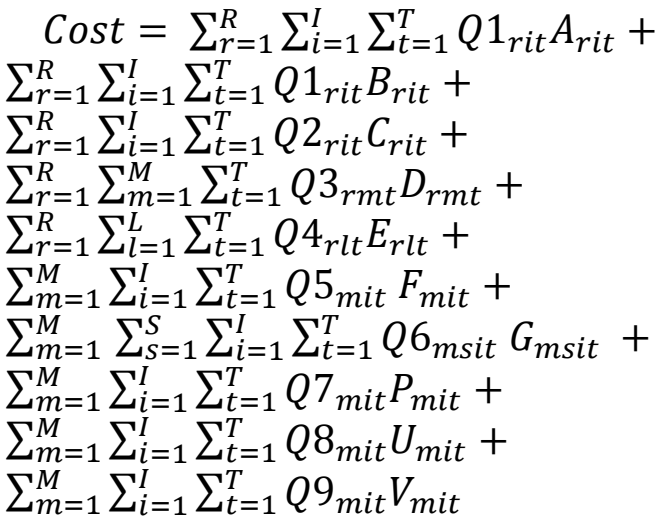

$\mathrm{R}$ is the number of Recovery Centres and $\mathrm{M}$ is the number of manufacturing plants. $\mathrm{O}$ is the number of routes to second markets and $\mathrm{L}$ is the number of landfill sites. $\mathrm{S}$ is the number of suppliers and $\mathrm{I}$ is the number of types of products. $\mathrm{T}$ is the number of periods of time.

$\mathrm{A}$ is the holding cost for returned products at the Recovery Centre warehouse and B is the disassembly cost. $\mathrm{C}$ is the refurbishment cost.

The transportation costs are: $\mathrm{D}=$ transportation cost to manufacture; $\mathrm{E}=$ transportation cost to landfill; $\mathrm{V}=$ transportation cost from manufacture plant to distributor.

$\mathrm{F}$ is the holding cost for parts at the Manufacturing Plant warehouse and $G$ is the new part cost from a supplier. $\mathrm{P}$ is the production cost and $\mathrm{U}$ is the new product holding cost at Manufacture Plant warehouse.

Q1 is the number of units of returned products and Q2 is the number of units that being refurbished. Q3 is the number of units sent to the manufacture plant and Q4 is the number of units sent to landfill. Q5 is the amount of raw materials at the Manufacturing Plant warehouse. Q6 is the number of new parts from suppliers and Q7 is the number of final products. Q8 is the number of new products at the Manufacture plant warehouse and Q9 is the number of units transported to distributors.

The objective of this model is to minimise cost, subject to the capacity of the recovery centre warehouse; manufacture plant warehouse; recovery centre labour available; manufacture production capacity; and demand of new products.

From this mathematical model, the author began to indentify how total cost was affected by returned products in the reverse supply chain. This was a first step in performance measurement.

\section{TESTING}

Secondary data was used for testing due to a lack of primary data. An excel program was produced to represent the models. A screenshot of a worksheet is shown in figure 6. Demand for the product was calculated and can be seen in Figure 7. From this demand, a forecast for demand was counted and shown in Figure 8.

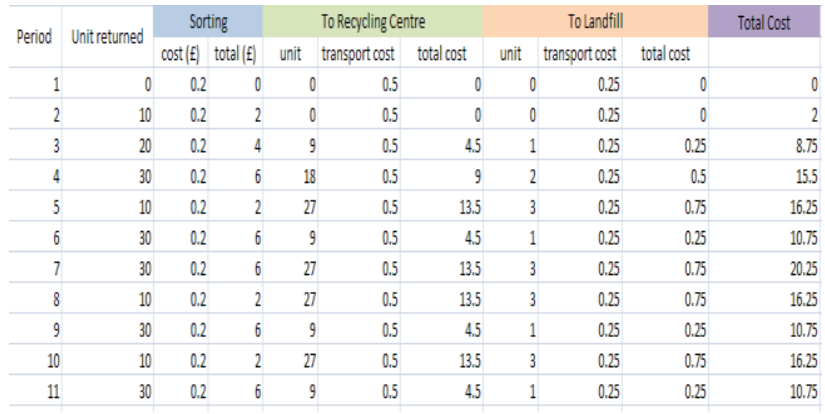

Figure 6. Worksheet screenshot

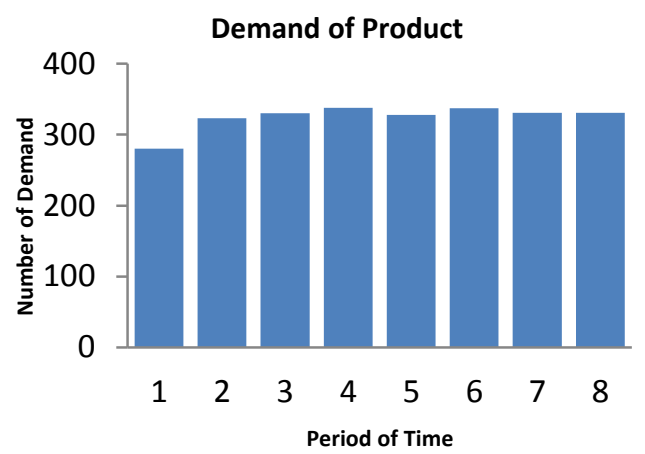

Figure 7. Demand of product

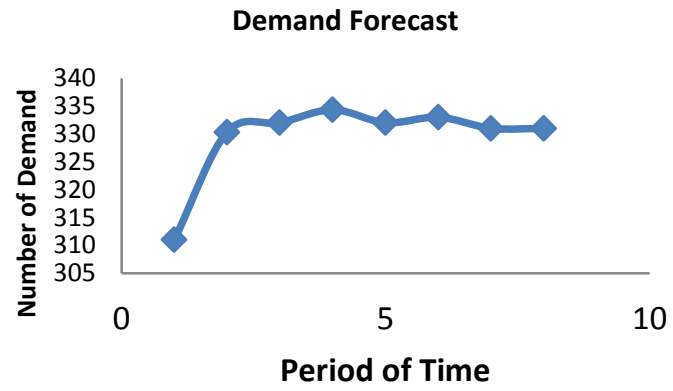

Figure 8. Demand forecast

\section{RESULT}

The forecast demand was applied to the mathematical model to see how the cost was affected by returned products. The model was tested with a low number of returned products and a high number of returned products. Total cost per period of time can be seen in Figure 9 for the high number of returned products and Figure 10 for the low number of returned products. 
Total Cost

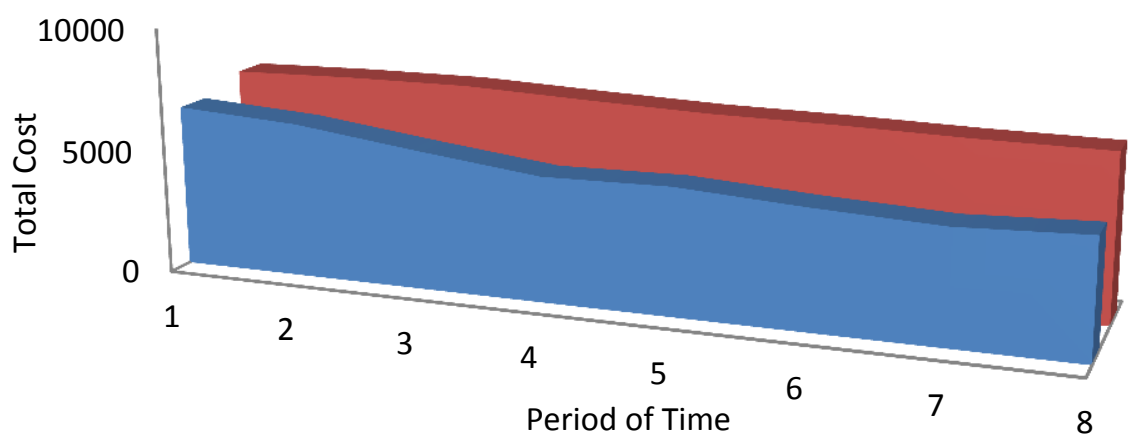

- High return product

Low return product

Figure 11. Total cost for high return product vs low return product

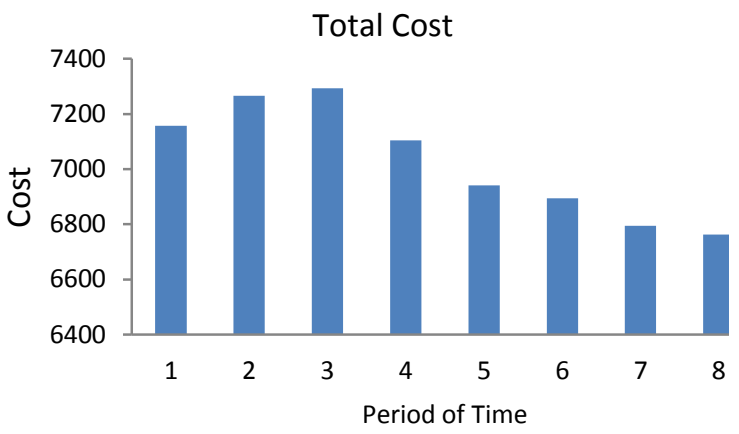

Figure 9. Total cost for high number of return products

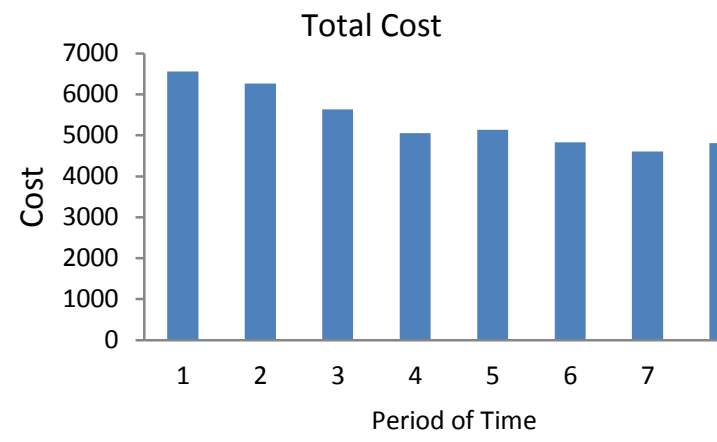

Figure 10. Total cost for low number of return products

These graphs, are discussed in the next sections.

\section{CONCLUNSION AND DISCUSSIONS}

With the same demand, total cost was different for each product. Returned products significantly affected total cost. The difference between a high number of returns compared with a low number of returned products affected the total cost as shown in Figure 11.

At the beginning of a period of time, it can be seen that cost for a low return product flow is lower than the cost for a high return product flow. That is because there is no cost in the Recovery Centre for a low return product flow.

In the Recovery Centre, total cost for a low returned product flow is lower than for a high returned product flow. Therefore, in future work an actual profit from selling the raw material from the scrapping process needs to be added to see how it affects Recovery Centre costs. As well as how re-sale-able products affect total cost.

In the next period of time, Figure 10 shown that a high returned product flow lowers the total cost compare to a low returned product flow. With re-usable raw materials from the Recovery Centre, new parts procurement will be reduced. That leads to cost reduction and more effective supply chain performance.

The model needs some improvement, for example:

- Primary data could be improved.

- It is better if sale price to second market and distributor is known to see how it affects profit.

- More specific investigation of which part of the process affect, total cost the most.

This is the first time that an attempt to measure performance in a reverse supply chain of carpet industry has been published. The simple mathematical model was to make a company able to view their reverse supply chains more easy as well as to measure performance.

Most literature in the carpet industry focused on reverse supply chains only mentions metrics and none of the references described how to measure performance. Most references only focused on a recovery centre without considering the re-manufacturing process. In this paper, simple mathematic models are presented for industry with re-manufacturing process in general.

In the future, more could be explored, such as: which process in the reverse supply chain affected the systems performance the most and how to measure the performance of a reverse supply chain with environmental regulation as the objective.

\section{ACKNOWLEDGMENT}


Butar Butar thanks the Directorate General of Higher Education Indonesia for facilitating and supporting the study.

\section{REFERENCES}

[1] Shear, H., T. Speh, and J. Stock, Many happy (product) returns. Harvard business review, 2002. 80(7): pp. 16-17

[2] Campbell, D., 10 Red Hot BI Trends. Information Management, 2009.

[3] Rogers, D.S., R.S. Tibben-Lembke, and R.L.E. Council, Going backwards: reverse logistics trends and practices. Vol. 2. 1999: Reverse Logistics Executive Council Pittsburgh, PA.

[4] Blackburn, J.D., et al., "Reverse supply chains for commercial returns", California management review, pp. 622, 2004.

[5] Butar, M.B. and D. Sanders, "Improving Green Computing in Business Intelligence by Measuring Performance of Reverse Supply Chains", GSTF Journal on Computing. 3(1). 2013.

[6] Guide, V.D.R., T.P. Harrison, and L.N. Van Wassenhove, The challenge of closed-loop supply chains. Interfaces, 2003. 33(6): pp. 3-6.

[7] Blumberg, D.F., "Introduction to management of reverse logistics and closed loop supply chain processes", CRC Press. 2004:

[8] Van Wassenhove, L.N. and V. Guide, Closed-loop supply chains. 2003: Pittsburgh.

[9] Guide Jr, V.D.R.a.L.N.v.W., "The reverse supply chain", Harvard Business Review, pp. 25-26. 2002.

[10] Guide, V.D.R. and L.N. Van Wassenhove, Closed-loop supply chains: practice and potential. Interfaces, 2003. 33(6): pp. 1-2.

[11] Rogers, D.S. and R. Tibben-Lembke, "An examination of reverse logistics practices", Journal of business Logistics, 22(2): pp. 129-148. 2001

[12] De Brito, M.P. and R. Dekker, A framework for reverse logistics; Springer. 2004.

[13] Patterson, K.A., C.M. Grimm, and T.M. Corsi,"Adopting new technologies for supply chain management.", Transportation Research Part E: Logistics and Transportation Review, 39(2): pp. 95-121. 2003

[14] Moore, R., "Reverse Logistics-the least used differentiator", A UPS Supply Chain Solutions White Paper, Alpharetta, 2005.

[15] Fleischmann, M., et al., "Quantitative models for reverse logistics: a review", European journal of operational research, 103(1): pp. 1-17,1997.

[16] Rahimifard, A., S. Newman, and S. Rahimifard, "A webbased information system to support end-of-life product recover", Proceedings of the Institution of Mechanical Engineers, Part B: Journal of Engineering Manufacture, 218(9): pp. 1047-1057, 2004.

[17] Thierry, M., et al., Strategic issues in product recovery management. California management review, 1995. 37(2).

[18] Stock, J.R. and J.P. Mulki, "Product returns processing: an examination of practices of manufacturers, wholesalers/distributors, and retailers", Journal of business Logistics, 30(1): pp. 33-62, 2009.

[19] Neely, A., M. Gregory, and K. Platts, "Performance measurement system design: a literature review and research agenda", International journal of operations \& production management, 15(4): pp. 80-116,1995.
[20] Cuthberston, R. and W. Piotrowicz, "Supply chain best practices - identification and categorisation of measures and benefits", International Journal of Productivity and Performance Measurement, pp. 389-404, 2008:

[21] Lohman, C., L. Fortuin, and M. Wouters, "Designing a performance measurement system: A case study", European Journal of Operational Research, p p. 267-286, 2004:.

[22] Stock, J.R., "The 7 deadly sins of reverse logistics", Material handling management, pp. 55, 2001.

[23] Effort, C.A.R., Carpet America Recovery Effort 2002 Annual Report. Carpet America Recovery Effort: [Online]. https://carpetrecovery.org/resources/annual-reports/.

[24] Tonanont, A., Performance evaluation in reverse logistics with data envelopment analysis. 2009.

[25] Wang, Y., Carpet recycling technologies. Recycling in textiles, 2006: p. 58-70.

Maulida Butar Butar is a researcher at the University of Portsmouth, United Kingdom. She is studying Reverse Supply Chains and focusing on measuring performance.

Dr David Sanders is a Reader in Systems and Knowledge Engineering and leads the Systems Engineering Research Group at the University of Portsmouth.

Dr Regina Frei is a Lecturer in Manufacturing Systems and Supply Chain Management at the School of Engineering, University of Portsmouth. 
